\title{
'Emergent' media and public communication: Understanding the changing mediascape
}

\author{
JIM MACNAMARA* \\ University of Technology, Sydney
}

\begin{abstract}
Scholars and practitioners are widely agreed that media and public communication are undergoing significant change deserving of close attention and, along with widespread popular media discussion, a body of scholarly research on the changing $21^{\text {st }}$ century mediascape is emerging. The term 'new media' is widely used in the literature to describe interactive online communication forms including blogs, social networks, photo and video sharing sites, microblogging, and virtual worlds enabled by what is referred to as Web 2.0. A number of studies cite so-called 'new media' as the 'fourth media revolution' and make effusive predictions concerning their effects ranging from the "end of journalism" to the transformation of the public sphere through the birth of e-democracy. This paper critically reviews changes taking place and provides an overview of implications for public communication. It challenges the term 'new media', arguing that it is inaccurate and unhistorical, and attempts to look beyond hype and 'cyberbole' that often distort discussion to identify substantive changes taking place. It argues these are located in social and cultural practices rather than technology and explores four foundational shifts which have significant implications for media and all areas of public communication practice including journalism, political communication, advertising, public relations and organisational communication.
\end{abstract}

\section{Introduction}

A number of scholars and commentators describe early $21^{\text {st }}$ century developments in internet communication as another major revolution in systems of public communication and cultural production. Some suggest that the internet, and particularly Web 2.0, is as significant as moveable type printing developed in China around $1040^{1}$ and in Europe circa $1436-40^{2}$ which has been described by James Carey (2009) and Anthony Smith (1980) as the first communication revolution. Mark Balnaves, Stephanie Hemelryk Donald and Brian Shoesmith (2009) propose that there have been four revolutions in the history of media, citing creation of the Greek alphabet which led to writing as the first, followed by invention of the printing press, the development of broadcast media (radio and television), and arrival of the computer, the internet, and social media (p. 12).

Internet-based digital media have "brought about profound changes in the nature and organisation of contemporary communication", as Virginia Nightingale and Tim Dwyer (2007) state in New Media Worlds: Challenges for Convergence (p. 1). The effects are farreaching according to many scholars, impacting media institutions, journalism, political communication, advertising, public relations, communities, and individual social and cultural capital. For instance, in his award-winning book, Convergence Culture: Where Old and New Media Collide, Henry Jenkins (2006) says "media industries are undergoing another paradigm shift" (p. 5). Author of The Vanishing Newspaper: Saving Journalism in the Information Age, Philip Meyer (2008) says the internet is "as disruptive to today's newspapers as Gutenberg's invention of movable type was to the town criers, the journalists of the $15^{\text {th }}$ century" (para. 10). John Pavlik (2008) sees the rise of 'citizen journalism' 
publishing in blogs as a "sea change" with "far reaching implications for the nature and function of journalism in modern society" (p. 77). Martin Hirst and John Harrison (2007) argue that "not since the time of ancient Greece, where the birth of democracy occurred, has political communication been so dramatically altered" (p. 356).

In his historical review of media from parchment and printing to hypermedia, Ronald Deibert (1997) concludes: "that we are currently living through a revolutionary change in technologies of communication is beyond dispute" - although the effects of those technologies are subjects of considerable debate (p. 4). Douglas Rushkoff (2003) prefers to describe current ICT developments as a "renaissance", but also concludes that we are witnessing a major shift in human perspective and understanding (p. 32). Similar views have been expressed by Manuel Castells (2001) and Nicholas Negroponte (1996) who describes the internet as "10.5 on the Richter scale of social changes" (p. 204).

However, one has to be cautious in making claims for the significance of current media and communication developments, noting that James Beniger (1986) identified 75 books written between 1950 and 1984 claiming major societal transformations resulting from new communication technologies. In The Digital Sublime: Myth, Power and Cyberspace, Vincent Mosco (2004) warns of "seductive tales containing promises unfulfilled or even unfillable" (p. 24) and the 'spiral of hype' (p. 25) that drives digital mythology - what Steve Woolgar (2002) calls cyberbole. The ICT industry itself recognises this tendency to overly promote and exaggerate the capabilities and effects of new technologies. Gartner Research (2008) has developed a five-stage 'Hype Cycle' which it says all new technology passes through starting with a 'Technology Trigger' followed by a 'Peak of Inflated Expectations', after which sentiment sinks into a 'Trough of Disillusionment', before beginning to mature and grow on the 'Slope of Enlightenment', finally reaching a 'Plateau of Productivity'. Many ICTs do not get past the 'Peak of Inflated Expectations', as the 2000-2001 dot.com crash showed. Martin Hirst and John Harrison (2007) bluntly warn that "the internet has its share of hucksters, boosters, and proselytizers" (p. 216).

Putting aside commercial claims designed to market new technologies (which are not the focus of this article), caution still has to be exercised in relation to transformist views of the internet among scholars. A number of analyses have arrived at optimistic and Utopian views of online communication, such as those of Nicholas Negroponte (1995) in Being Digital, Howard Rheingold $(1993,2002)$ in The Virtual Community and Smart Mobs, Manuel Castells (1996, 2000, 2001, 2004) in his discussions of the "network society", and Yochai Benkler (2006) in The Wealth of Networks. Terry Flew (2008) notes that some analyses suggest that the evolving internet will transform society and the public sphere into a democratised and equitable public space offering access to all (p. 38). Writers in this tradition also see transformative effects for business, such as Chris Anderson (2006) in the The Long Tail.

On the other hand, pessimistic views see interactive internet media as inaccessible to many because of a 'digital divide' (National Telecommunications and Information Administration 2000; Norris 2001; Novak \& Hoffman, 1998), likely to be colonised by power elites (McChesney, 2008; Mosco 1996; Schiller, 2000), and/or subsumed within existing social, cultural and political practices (Miller \& Slater, 2000). Daniel Miller and Don Slater (2000) say that Castells $(1996,2004)$ "overestimates the transformative impact of new media technologies ... and underestimates the extent to which new media are incorporated into an already existing repertoire of socio-cultural activities and relationships". Political economist Robert McChesney (2000) argues that "despite its much-ballyhooed openness [the internet] will likely be dominated by the usual corporate suspects" (pp. 33-34), a position supported 
by a number of political economist including Vincent Mosco (1996, 2009) and Herbert Schiller (2000). Sociologist Zygmunt Bauman accuses Castells, Benkler, Lash (2002) and other internet optimists of "internet fetishism fallacy" (as cited in Deuze, 2007, p. 33).

A way through this polarised debate is made available by integrating political economy views which focus on the top-down influence of capitalism and powerful institutions with cultural studies views which focus on audience agency including resistance to media messages, usergenerated content, and popular culture. Chris Newbold, Oliver Boyd-Barrett and Hilde Van Den Bulck (2002) were among the first to note benefits of an integrated approach, commenting that "it is becoming more common for studies to integrate political economy and cultural studies traditions" (p. 40). John Corner (2000) says that the "contested core of media research" can be resolved through "interdisciplinary perspectives" (p. 388) and in a recent book chapter titled 'Bridging the mythical divide', Natalie Fenton (2007) presents a compelling case for "a holistic approach" to the media by combining political economy and cultural studies perspectives. Fenton says that "once the role of production passes to the consumer, as in much alternative media production, the nature of the beast changes, but it is still circumscribed in the social structures from which it emerged" (p. 21). In short, a multidisciplinary approach provides a framework for critically analysing both gloom and doom predictions and transformist Utopian views.

At its most basic level, overstatement, hype and confusing discourse concerning emerging digital forms of communication is evident in generalisation of these as 'new media'. Many authors use the term 'new' as a category of media including Leah Lievrouw and Sonia Livingstone (2005) in The Handbook of New Media; Martin Lister et al. (2003) in New Media: A Critical Introduction; Lisa Gitelman and Geoffrey Pingree (2003) in their edited volume on New Media; Terry Flew (2008) in New Media: An Introduction; Martin Hirst and John Harrison (2007) in Communication and New Media; Virginia Nightingale and Tim Dwyer (2007) in New Media Worlds: Challenges for Convergence; and Wendy Hui Kyong Chun and Thomas Keenan (2006) in their New Media: Old Media. In most uses, the term 'new media' is inaccurate. Some media that Lisa Gitelman (2008) says are "familiarly and collectively referred to as "new media"' (p. 1) can hardly be accurately described as new. Online chat and an early form of online social networks have existed since 1979 when Duke University graduate students Tom Trucott and Jim Ellis created Newsgroups, online chat rooms similar to bulletin boards on Usenet, a pre-Web text-only section of the internet (Hauben \& Hauben, 1998). The first online journal in a format later to be called a blog was published by Claudio Pinhanez in 1994 on the MIT Media Lab Web site. The term Web log or Weblog was created in 1997 (Wortham, 2007), before being shortened to 'blog' in 1999 by pioneering blogger Peter Merholz (1999). The first online social network in the modern form, SixDegrees, was established in 1997 and reached several million members before it closed in 2001 (Boyd \& Ellison, 2007). So online chat has celebrated its $30^{\text {th }}$ anniversary, blogs have existed for 15 years, and modern online social networks for more than a decade. Google celebrated its $10^{\text {th }}$ anniversary in 2008 and podcasting turned 10 in 2010. Even though MySpace, Facebook and YouTube were established more recently in 2003, 2004 and 2005 respectively, these emergent internet media are rapidly losing any sense of 'newness' with almost a billion users (Macnamara, 2010).

Users of the term 'new media' themselves admit ambivalence. In their introduction, Virginia Nightingale and Tim Dwyer (2007) say "we chose the title New Media Worlds knowing that there is currently considerable debate about whether and to what extent there is in fact anything 'new' about the changes associated with digital media" (p. xxiii). As Terry Flew (2008) acknowledges: 
Digital media technologies are now so pervasive in our work, our home lives, and the myriad everyday interactions we have with each other as well as with social institutions, that they are ceasing to be 'new' in any meaningful sense of the term (p. 2).

As well as being largely inaccurate by most definitions of 'new', the term 'new media' is relative and time-bound, meaning it will become increasingly problematic as further developments occur. Describing media in this way is, at best, a temporary step and contributes little to understanding their distinctive characteristics. At worst, it is unhistorical ignoring the long history of mediated communication and the associated social and cultural practices which can inform current and future analyses. Some, such as Fernando Bermejo (2009), argue that use of the term 'new media' does not refer to their novelty, but rather serves as a conceptual tool to identify and examine media at a particular "historical occasion". However, a third reason that the term 'new media' is unsatisfactory is that it obscures developments occurring within what are categorised explicitly or by default as 'old media' or 'traditional media' and leads to either-or binary thinking and what John Seely Brown calls endism (Brown \& Duguid, 2000). George Gilder (1994) confidently predicted that the internet would mean the end of television. In the same year, Roland Rust and Richard Oliver (1994) declared the death of mass media advertising. In his book The Vanishing Newspaper: Saving Journalism in the Information Age, Philip Meyer (2004) applied US newspaper readership trend data between 1967 and 2002 to plot a line showing newspaper readership reaching zero in April 2043. UK media commentator Roy Greenslade offers no date, but he told a May 2008 'Future of Journalism' summit in Sydney that "popular newspapers, the mass newspapers, are dying and will die" (Este et al., 2008, p. 4).

Such claims are not new in relation to media. When video cassette recorders (VCRs) entered the market in the 1970s with JVC's VHS standard and Sony's Beta format fighting a decadelong battle for market share, followed by the even-greater popularity of CDs and DVDs, doomsayers predicted the end of cinema (Lewis, 2001). Some 40 years on, the movie industry has adjusted, adapted and continued to produce more 'blockbusters' for the big screen than ever before. Television and newspapers, while undergoing change, continue to exist. And most rational analyses suggest that they will for some time yet.

'New media' fetishism and endism ignore counter forces that proponents of particular changes fail to see or afford due valence. To predict the end of newspapers assumes that Rupert Murdoch and other 'media barons' will readily accept the loss of billions of dollars invested in print-based media and broadcast networks and will not seek to modernise their products and defend their market share. Further, it ignores the reality that, despite a narrowing digital divide, many parts of the world such as sub-Sahara Africa and Central and South American countries are likely to rely on printed information for some time into the future. It also ignores trends in some rapidly developing parts of the world such as India where increasing education and an expanding middle class, coupled with regulatory regimes and political policies, are leading to increasing use of newspapers, radio and television in parallel with rapid growth in use of new forms of digital media.

Adoption of an interpretative framework that considers functional as well as dysfunctional aspects of media developments, and views media in a historical context, sidesteps simplistic binary arguments and endism and affords understanding on the complex nature of changes occurring. Four foundational shifts can be identified from such an analysis. 


\section{Mediamorphosis}

The mediascape of the future is likely to be characterised by what Roger Fidler (1997) calls mediamorphosis referring to the morphing of media types and forms. Already print reporters are recording photographs, video and sound as well as text and directly posting content online via wireless internet connection - referred to as 'MOJO's' for mobile journalists (Quinn 2008) and "backpack journalists" (Stone, 2002). All major newspapers and broadcast networks have online editions and many are among the most popular sites on the Web (e.g. The Guardian online). Radio and television are also moving to the internet, such as the Australian Broadcasting Corporation which extensively podcasts programs. Newspapers and radio and television networks are also adapting to interactive content formats. These include journalist blogs and comment sections in online media sites that accept and in some cases encourage citizen contributions. Some traditional media are going even further and launching online sites comprised largely or wholly of citizens' views such as Punch published by News Limited, the new National Times produced by Fairfax Media, and the ABC's Pool described as "an online town square for all Australians" (www.pool.org). Notwithstanding concerns over accuracy and some skirmishes over territoriality, citizen journalism is carving a space in the mediascape, and media users increasingly source news and information from Web sites, blogs, YouTube and Twitter as well as traditional media sources.

Along with convergence (Jenkins, 2006) and hybridising media types and forms, a number of studies identify increasing intermediation - the sharing and transfer of content between media types (Danielian \& Reese, 1989; Severin \& Tankard, 2001, p. 232). Jay Bolter and Richard Grusin (2000) have similarly discussed remediation drawing on Marshall McLuhan's (1964) view that "the content of any medium is always another medium" (p. 8). Bolter and Grusin say "no medium ... can now function independently and establish its own separate and purified space" (p. 55). In Convergence Culture, Henry Jenkins (2006) gives the example of Big Brother which involves broadcast television as well as Webcasting, interactive viewer voting by phone and Short Message Service (SMS) text, and fan communities in both the physical world and online (so-called virtual communities).

Media history suggests that mediamorphosis and hybridisation will continue. When radio was commercialised in the 1920 and 1930s, new audiences were created alongside newspaper readers and the two media co-existed. Likewise, when television was launched in the 1940s and 1950s, newspapers, magazines and radio continued and their audiences increased. For instance, newspapers reached their highest circulation in the US in 1984 - 40 years after the introduction of television. In fact, newspapers and magazines prospered, in part by publishing TV schedules and reporting on programs and stars. Recently, the introduction of computer games has led to further predictions of the end of other forms of screen entertainment, but the market has continued to expand and coalesce. History shows that in the face of technological change and shifting audience interests, media adapt, share content, partner and evolve. Change also meets headlong with the force of inertia in terms of audience habits as well as institutional structures and processes.

\section{Collapse of the control paradigm and 'emergence'}

While historical lessons and current trends of mediamorphosis and hybridisation suggest a continuation of the status quo to some extent, there are within this evolving media ecosystem dynamic changes that are challenging traditional media institutions and fundamentally reshaping media and public communication practices. It is not possible in this paper to 
discuss the myriad micro and sector-specific changes that are occurring, but many of these will be enabled and given impetus by one major shift in the tectonic plates of the mediascape.

Throughout the $19^{\text {th }}$ and $20^{\text {th }}$ centuries, media became increasingly concentrated, reaching a point at the beginning of the early $21^{\text {st }}$ century when five corporations - Time Warner, Disney, News Corporation, Viacom and Bertelsmann - dominated the output of daily newspapers and magazines, broadcasting, books and movies worldwide (Bagdikian, 2004). This indicates a high level of economic control. But another form of control is as, or more, significant in traditional mass media models. In newspapers, magazines, radio and television, the predominance of content is provided and controlled by media 'gatekeepers' in the case of editorial and by advertisers in the case of paid media advertising. Sociologist Franco Ferrarotti (1988) describes the social impact of mass media as "the end of conversation" in a book of that title. In mass media, beyond small spaces for letters to the editor and caller comments on talkback radio, access and content are controlled by media professionals and political economy elites as part of what James Beniger (1986) calls the "control revolution".

In a speech to the American Society of Newspaper Editors in April 2005, Rupert Murdoch (2005) acknowledged that he grew up in a period when "news and information were tightly controlled by a few editors who deigned to tell us what we could and should know". He went on to note that today's media users "don't want to rely on a god-like figure from above to tell them what's important. And to carry the religion analogy a bit further, they certainly don't want news presented as gospel". Geert Lovink (2007) similarly, if provocatively, describes mass media content as "lecture".

This control paradigm of media is collapsing. Use of the term 'collapse' is not meant to suggest that there is no longer any control of media content. That is far from the case and will be for some time to come, as suggested by the hybridised model discussed in the previous section in which major media organisations are likely to continue to operate. However, even though some media content will remain controlled by media 'gatekeepers' or advertisers, proliferation of new forms of media such as blogs, microblogging (e.g. Twitter), social networks, and 'broadcast yourself' networks such as YouTube, means that citizens are no longer denied a voice. There is still much to debate about the relative power or influence of that voice and the problematic issue of gaining audiences, but to some extent at least, "the people formerly known as the audience" (Rosen, 2006) are no longer simply consumers of media content and are no longer deprived access to powerful tools of public communication.

This deeply significant change is not the result of a voluntary opening up of media by media barons or 'gatekeepers' or intervention by authorities. A noteworthy feature of changes taking place is that they have occurred mostly spontaneously and chaotically, unplanned and largely unforeseen by the major power elites of government and industry. It can be argued that media and public communication today are emergent. Emergence refers to "the appearance of entirely new properties at certain critical stages or levels in the course of evolution" of a species or system (Macquarie Dictionary 2008). But what is significant about emergent changes is that they are not linear or cumulative as occurs in the usual progress of evolution, and they are not centrally controlled. Rather, they arise unpredictably and unforeseen, triggered by self-organising characteristics in species and communities.

Yochai Benkler (2006) is one of a number of scholars who have observed a "self-organising principle" at work in Web 2.0 environments (p. 255). Other writers who have noted emergent properties in media include Douglas Rushkoff (2003, p. 50), Virginia Nightingale (2007, pp. 291, 304) and Steven Johnson (2001) who likens online human activity to slime mould, citing 
similarities with emergent biological forms. While a connection between human activity and slime mould seems "preposterous", as Douglas Rushkoff (p. 50) has noted, sequestering of the term 'emergent' is useful in drawing attention to the nature of changes occurring. In his book titled Emergence, Johnson (2001) argued that all media can exhibit emergent properties, but that interactive internet applications in particular are emergent, moving beyond hierarchal or central control to decentralised self-organising operation and regulation. Drawing on Marshall McLuhan's (1964) classic duality of medium and message and more recent research focussing on the importance of audience including the existence of audience agency in communication processes, Johnson identifies traditional mass media such as television as involving these three key elements - a medium, messages and audience arranged in a hierarchal relationship in this order. In mass media, the rules of engagement for both production and consumption of content are prescribed by media institutions. In interactive internet media, he says the rules that govern the way messages flow through the system are not imposed top-down as in most systems and endemic to the system (e.g. the medium), but are self-organised, often from "bottom-up" (Johnson, 2001, pp. 148-58). Furthermore, Johnson argues that the key characteristic or condition that enables these rules to be created independently is interactivity.

Erik Bucy (2004) notes that interactivity is the defining element of contemporary Web communication, although Martin Lister et al. (2003) point out that, while being one of what they see as five defining concepts characterising 'new media', interactivity itself is ill-defined and contentious (p. 11). Johnson agrees that the term 'interactivity' "doesn't do justice to the significance of this shift" and needs clarification (p. 158). Nico Carpentier (2007, p. 221) identifies important distinctions between person-to-machine (Human Computer Interaction) and person-to-person interaction discussed by a number of authors including John Carey (1989) and Donna Hoffman, Thomas Novak and Ann Schlosser (2000). Sally McMillan (2002) identifies three levels of interaction which she describes as user-to-system interactivity, user-to-documents interactivity, and user-to-user interactivity (pp. 166-72) distinctions that Carpentier attributes to earlier writing by Bohdan Szuprowicz (1995). Userto-system interactivity, or person-to-machine interaction in Carpentier's terms, is largely a given in any computer-mediated communication (CMC) and internet use. While access to computer system resources and functions affects outcomes, it is particularly the higher levels of interactivity that provide the impetus for emergence in Web 2.0 and the genres of media that it enables. Even user-to-documents interactivity, when confined to read-only access documents, is restrictive and typical of 'closed' hierarchally controlled communication systems. This suggests a further key element to add to Johnson's four-part emergent media model that has to pre-exist and in turn characterizes the type of interactivity involved - that is, systems, documents and user interaction have to be open.

Open is another relative term, but Axel Bruns (2005) has provided some definition and description to give clarity and specificity to what we might mean by open media. Bruns proposes that there are levels of openness for interaction at input, output and response stages of media production. But rather than fixed descriptions or markers for openness, he discusses a "continuum of openness" in media (p. 124). This continuum ranges from the online editions of major newspapers and radio and TV networks where the division between producers and users remains but there is scope for comment and feedback; through 'gatekeeping lite' sites that encourage and promote user contributions; editor-assisted open news models such as South Korea's ohmynews. $\mathrm{com}^{3}$ and Media Channel in the US; to fully open media at the most democratic end of the spectrum (Flew, 2008, p. 145). Expanding on Bruns' definition and discussion, it can be seen that openness begins at a basic level of machine interactivity such as menu selection (although it is arguable whether this is open in any significant sense), and 
moves along a continuum to open access (e.g. free rather than subscription or purchase), open to comment or feedback, open to contributions, open to editing (e.g. Wikipedia) and, finally, open for full production and control (e.g. YouTube and blogs). Bruns' "continuum of openness" is useful in avoiding a limiting binary of pronouncing media and interaction either open or closed. It recognises that media are situated along a continuum from fully open to fully closed with many permutations in between.

Brian McNair (2006) notes that an outcome of this decentralisation, collapse of control, and democratisation of media will be "cultural chaos". Many editors, journalists, politicians, advertising executives and public relations practitioners agree and express grave concerns about "a disappearance of truth" when anyone can publish or broadcast, unfiltered opinion undermining the public sphere, and a looming collapse of traditional media business models. Andrew Keen's (2007) Cult of the Amateur, Geert Lovink's (2007) criticisms of "pyjama journalists", and an outburst by CEO of News Limited in Australia, John Hartigan (2009) at the National Press Club in Canberra in which he referred to blogs as "something of such limited intellectual value as to be barely discernible from massive ignorance" are examples. However, McNair was not discussing cultural chaos in an entirely pejorative sense. Rather, he notes, with some positive anticipation, that dominant ideologies and power elites are being challenged, and non-elites have an increased voice in a communication environment that is unpredictable, pluralised and competitive.

Decentralisation, interactivity and openness for user-generated and user-modified content characterise what Mark Poster (1995) calls the "second media age" in contrast with the first media age noted for centralised control and top-down information transmission. While the term revolution is over-used, it is argued that, with openness for user-to-documents interactivity and user-to-user interactivity, along with openness of access and intellectual property, Web 2.0 media and public communication practices are emergent. They are technologically underpinned primarily by open source software rather than software developed by leading ICT companies - although the latter have been quick to capitalise on the growth of online communication. Much of the content of what are called emergent media and public communication practices in this paper is created through grassroots collaboration harnessing 'collective intelligence' (Lévy, 1997) and distributed through social networks. As such, these developments are largely self-organising, bottom-up, unpredictable and uncontrolled in the way that media and public communication have been controlled in the first media age.

\section{Media as practices, not technologies}

Technological determinism continues to rear its head in many discussions of the Web and media, but the previous discussion suggests that emergent media and public communication are best understood in terms of social and cultural practices rather than technologies. A number of architects of the Web and scholars have made this point. For instance, pioneering blogger Peter Merholz (2005) who created the abbreviation 'blog' in 1999 from the term "Weblog ${ }^{4}$ says bluntly "it's not about the technology" (para. 5). In a feature titled "What is Web 2.0' in the online ICT industry journal ZDNet, Richard MacManus (2005) notes that it is a 'platform' but also states that it is "an attitude not a technology", specifically "the underlying philosophy of relinquishing control" (paras 3-5). While many have interpreted Henry Jenkins' (2006) Convergence Culture as referring to converging technology in a digital environment, Jenkins emphasises that convergence is about culture more than technology and, in particular, "participatory culture" (p. 243). Many other commentators and 
writers similarly discuss "the Web 2.0 philosophy of community, sharing and user-created content" (Fost \& Lee, 2006, para. 5).

Alvin Toffler $(1970,1980)$ first prophesised the rise of the prosumer, the consumer who is also a producer of media content, more recently termed a produser by Axel Bruns (2005). What Charles Leadbeater and Paul Miller (2004) call the PRO-AM revolution referring to crossing of the professional/amateur divide in media production is evident today in 133 million blogs indexed and tracked by Technorati (2009) not including most of 162 million blogs in China (China Internet Network Information Center, 2009). Worldwide membership of social network sites reached 580 million in mid-2008, according to comScore (2008), with Facebook the leader at that time with 132.1 million active monthly users, followed by MySpace with 117.6 million users. Since, according to Facebook's own statistics, its membership passed 400 million in early 2010 (Facebook Factsheet, 2010) and surged to 500 million by July 2010 (Facebook, 2010). In the same month, more than two billion videos a day were being viewed on YouTube (YouTube, 2010). In addition, millions of text, photographic and video contributions are provided by citizens to press, radio and television and billions of SMS/MMS/IM messages and 'tweets' in Twitter are posted annually. All of these communication environments are enabled by free, open source software and accessible through any standard Web browser. As such, it is clear that the site of emergence in $21^{\text {st }}$ century media and public communication is the field of practice rather than technology which has become increasingly standardised and commonplace.

Drawing on practice theory emanating from sociology and anthropology (Reckwitz, 2002; Schatzki, 1999), Nick Couldry (2004) proposes 'media as practice' as a model for media study in place of previous media effects, political economy, cultural studies and semiotic traditions. Specifically, Couldry argues that contemporary media and public communication are distinctive because of interlocking practices of production, practices of distribution, and practices of consumption. He says the focus should be what people do with media and around media, rather than how media are structured or what media do. Media as practice provides a lens through which the diverse range of media practices today can be understood. The principal site of change and emergence is the practices of public communication and mediation and the wider social and cultural practices in which they are framed.

\section{The rediscovery of public conversation}

While sociologist Franco Ferrarotti (1988) described the rise of mass media as "the end of conversation", many herald the rediscovery of conversation as one of the most significant affordances of the open, uncontrolled emergent mediascape that is enabled by Web 2.0. As G. Stuart Adam (2009) remarked in the foreword to the 2009 revised edition of James Carey's classic Communication as Culture, the term 'conversation' is so familiar that its significance can be easily overlooked. Carey cites philosopher Kenneth Burke (1957) who said "life is a conversation" and Martin Heidegger (1969) who said "we - mankind - are a conversation" (p. 277). Carey (2009, p. 65) explains that humans seek to establish coherence and order in the world to support their purposes, and the primary method by which they do that collectively is communication carried out interactively through conversation. John Dewey (1927) argued similarly, noting that the means of communication with the greatest equality, flexibility and accessibility is conversation. As Carey (2009) says, "we can all talk" by which he means conversing through writing as well as speaking (p. 67). However, drawing from John Dewey, Carey warns that language, the fundamental medium of human life, has increasingly become conceptualised as an instrument for manipulating others and getting them to believe what we 
want them to believe, rather than as a collectively applied means for negotiating meaning and building culture and relationships (p. 64).

Unlike mass media in which all information and viewpoints are transmitted to 'audiences' in a top-down monologue, dialogue and conversation are the preferred mode of engagement in Web 2.0 online communities. These related concepts - different only in that conversation is largely unstructured and vernacular while dialogue can be more formal and structured - both require authenticity as one of their key properties and this concept receives considerable attention in online environments. While a normative and often subjective concept, authenticity is surprisingly well recognised and quickly detected on the internet - or often it is the lack of authenticity that is recognised and earns the ire of online communities. Drawing from several intellectual traditions, Richard Johannesen (1990) identifies five characteristics of authentic dialogue including honesty and accuracy, genuineness, empathy, and a "spirit of mutual equality". As well as adhering to fundamental requirements such as being truthful, these characteristics of authentic dialogue mean that communicators need to speak in their own voice and the process must involve two-way interaction to hear and consider the views of others, including dissent and even criticism. What Martin Buber $(1958,2002)$ identified as authentic dialogue is distinguishable from monologue and "monologue disguised as dialogue" both in face-to-face communication and in online communication.

In place of traditional media "lecture" (Lovink, 2007), "gospel" (Murdoch 2005) and "sermon" ("It's the links stupid", 2006), interactive Web 2.0 media facilitate conversation. In an interview with The Economist discussing blogs and other forms of interactive media, cofounder of Hotmail, Sabeer Bhatia, predicted "journalism won't be a sermon any more, it will be a conversation" ("It's the links stupid", 2006). While many journalism and media scholars argue with considerable justification that a role remains for 'gatekeepers' who fact-check, analyse, and summarise the vast and increasing array of information available, journalism is increasingly opening its doors to citizen comment, public contributions and, if somewhat reluctantly, even to citizen journalism. Governments, faced with declining support for and engagement in traditional political institutions, are seeking to revitalise the public sphere through e-democracy - engaging citizens online in discussion forums and consultation (Jenkins, 2006, p. 209; Macnamara, 2008, 2009; Smith \& Rainie, 2008). In an attempt to remain relevant and survive as a major business model, advertising is being forced to change with a shift from transmission of centrally-produced and controlled advertising messages to interactive advertising, viral campaigns in which consumers participate in distribution, and even to fully user-generated advertising (Wells et al. 2008). Public relations, which in normative models emphasises two-way interaction (Grunig \& Hunt, 1984; L. Grunig, J. Grunig \& Dozier, 2002) but in practice relies often on one-way transmission of information such as media releases, speeches and newsletters, is having to broaden its focus to include engagement through blogs, social networks, online chat, and microblogging such as Twitter. Reputations and brands can be made or broken in these environments, but the 'push' model of information is challenged in them. Web 2.0 media and communication environments are open-ended ongoing conversations, as uncontrolled, vernacular, variable and occasionally misguided as other human conversations. Ultimately, Web 2.0 is a philosophy as Tim O'Reilly (2005), Peter Merholz (2005), Richard McManus (2005) and others say. It asks whether we have faith in the ability of humans to create and maintain a civil society through 'collective intelligence' (Lévy, 1997), conversation and collaboration, or whether we believe in elite culture and power relations didactically informing and manipulating citizens through propaganda - whether it be sinister or 'white propaganda' (Jowett \& O'Donnnell, 2005, p. 16). 
Although this fourth media revolution is causing considerable concern and some anxiety, it should come as no surprise. Megan Boler (2008, p. 39) notes that "the Web has always been about voice and conversation" and cites Web founder Tim Berners-Lee who said the Web was never intended to be about delivering content to passive audiences, but to be about "shared creativity". In this sense, the Web in its second iteration is only beginning to realise the goals of its founders. Despite a range of risks and dysfunctions including social inequities because of a digital divide, potential information overload, distribution of misinformation, and rising concerns over privacy, the scaffolding of Web 3.0 is already being constructed and promises to be a site of further emergence in media and public communication. This emergence is occurring in practices more than technologies and these are insightfully informed by a historical and socially-situated analysis of human communication rather than focus on novelty and 'newness'.

\section{References}

Adam, G. (2009). Foreword. In J. Carey, Communication as culture. New York: Routledge.

Anderson, C. (2006). The long tail. New York: Hyperion.

Balnaves, M., Donald, S., \& Shoesmith, B. (2009). Media theories and approaches: A global perspective. Basingstoke, UK: Palgrave Macmillan

Bagdikian, B. (2004). The new media monopoly. Boston, MA: Beacon.

Beniger, J. (1986). The control revolution: Technological and economic origins of the information society. Cambridge, MA: Harvard University Press.

Benkler, Y. (2006). The wealth of networks: How social production transforms markets and freedom. New Haven, CT: Yale University Press.

Bermejo, F. (2009). Audience manufacture in historical perspective: From broadcasting to Google. New Media \& Society, 11(1\&2), 133-154.

Boler, M. (Ed.). (2008). Digital media and democracy: Tactics in hard times. Cambridge, MA: MIT Press.

Bolter, J., \& Grusin, R. (2000). Remediation: Understanding new media. Cambridge, MA: MIT Press.

Boyd, D., \& Ellison, N. (2007). Social network sites: Definition, history and scholarship. Journal of Computer-Mediated Communication, 13(1), Article 11. Retrieved from http://jcmc.indiana.edu/vol13/issue1/boyd.ellison.html

Brown, J., \& Duguid, A. (2000). The social life of information. Boston, MA: Harvard Business School Press.

Bruns, A. (2005). Gatewatching: Collaborative online news production. New York: Peter Lang.

Bruns, A. (2008). Blogs, Wikipedia, Second Life and beyond: From production to produsage. New York: Peter Lang.

Buber, M. (1958). I and thou (W. Kaufmann, Trans.). New York: Charles-Scribner.

Buber, M. (1987). I and Thou ( $2^{\text {nd }}$ ed.) (R. Smith, Trans.). New York: Scribners. (Original work published 1923)

Bucy, E. (2004). Interactivity in society: Locating an elusive concept. Information Society, 20(5), 373-383.

Burgess, J. (2006). Hearing ordinary voices: Cultural studies, vernacular creativity and digital storytelling. Journal of Media and Cultural Studies, 20(2), 201-214.

Burke, K. (1957). The philosophy of literary form. New York: Vintage Books.

Carey, J. (1989). Interactive media. In E. Barnouw (Ed.), International encyclopaedia of communications (pp. 328-330). New York: Oxford University Press.

Carey, J. (2009). Communication as culture. New York: Routledge. (Original work published 1989)

Carpentier, N. (2007). Participation, access and interaction: Changing perspectives. In V. Nightingale \& T. Dwyer (Eds.), New media worlds: Challenges for convergence (pp. 214-230). South Melbourne: Oxford University Press.

Castells, M. (1996). The rise of the network society. Oxford, UK: Blackwell Publishers.

Castells, M. (2000). The rise of the network society ( $2^{\text {nd }}$ ed.). Oxford, UK: Blackwell Publishers. 
Castells, M. (2001). The internet galaxy: Reflections on the internet, business, and society. New York: Oxford University Press.

Castells, M. (2004). Afterword: Why networks matter. In H. McCarthy, P. Miller, \& P. Skidmore (Eds.), Network logic: Who governs in an interconnected world? (pp. 221-224). London: DEMOS.

China Internet Network Information Center. (2009). $23^{\text {rd }}$ statistical survey report on the internet development in China. Retrieved from http://www.cnnic.cn/uploadfiles/pdf/2009/3/23/131303.pdf

Chun, W., \& Keenan, T. (2005). New media, old media: A history and theory reader. London: Routledge.

comScore. (2008, August 12). Social networking explodes worldwide as sites increase their focus on cultural relevance [press release]. Retrieved from http://www.comscore.com/press/release.asp?press=2396

Corner, J. (2000) Influence: The contested core of media research. In J. Curran \& M. Gurevitch (Eds.), Mass media and society (3rd ed., pp. 376-397). London: Arnold

Couldry, N. (2004). Theorizing media as practice. Social Semiotics, 14(2), August), 115-132.

Danielian, L., \& Reese, S. (1989). A closer look at intermedia influences on agenda setting: The cocaine issue of 1986. In P. Shoemaker (Ed.), Communication campaigns about drugs: Government, media and the public (pp. 47-66). Hillside, NJ: Lawrence Erlbaum Associates.

Deibert, R. (1997). Parchment, printing, and hypermedia: Communication in world order transformation. New York: Columbia University Press.

Deuze, M. (2007). Media work. Malden, MA and Cambridge, UK: Polity Press.

Dewey, J. (1927). The public and its problems. New York: Henry Molt \& Co.

Este, J., Warren, C., Connor, L., Brown, M., Pollard, R., \& O’Connor, T. (2008). Life in the clickstream: The future of journalism. Sydney: Media Arts \& Entertainment Alliance. Retrieved from http://www.alliance.org.au/documents/foj_report_final.pdf

Facebook. (2010). Scaling Facebook to 500 million users and beyond. Facebook engineering notes. Author. Retrieved from http://www.facebook.com/note.php?note_id=409881258919

Facebook Factsheet. (2010). Facebook. Retrieved from http://www.facebook.com/facebook?ref=pf\#/press/info.php?factsheet

Fenton, N. (2007). Bridging the mythical divide: Political economy and cultural studies approaches to the analysis of media. In E. Devereux (Ed.), Media studies: Key issues and debates (pp. 7-31). London: Sage.

Ferrarotti, F. (1988). The end of conversation: The impact of mass media on modern society. New York: Greenwood.

Fidler, R. (1997). Mediamorphosis: Understanding new media. Thousand Oaks, CA: Pine Forge.

Flew, T. (2008). New media: An introduction ( $3^{\text {rd }}$ ed.). South Melbourne: Oxford University Press.

Gartner Research. (2008). Hype cycles: Interpreting technology hype. Retrieved from http://www.gartner.com/it/products/research/methodologies/research_hype.jsp

Gilder, G. (1994). Life after television. New York: W.W. Norton \& Company.

Gitelman, L. (2008). Always already new: Media history, and the data of culture. Cambridge, MA: MIT Press.

Gitelman, L., \& Pingree G. (Eds.). (2003). New Media: 1740-1915. Cambridge, MA: MIT Press.

Grunig, J., \& Hunt, T. (1984). Managing public relations. Orlando, FL: Holt, Rinehart \& Winston.

Grunig, L., Grunig J., \& Dozier D. (2002). Excellent organisations and effective organisations: A study of communication management in three countries. Mahwah, NJ: Lawrence Erlbaum Associates.

Hartigan, J. (2009, July 1). Australia's right to know: Freedom of speech campaign. Speech to the National Press Club, Canberra, Australia. Retrieved from http://www.crikey.com.au/2009/07/01/hartigan-the-blogosphere-is-all-eyeballs-and-no-insight/

Hauben, M., \& Hauben R. (1998, July 6). The evolution of UseNet: A poor man's ARPANET. First Monday, 3(7). Retrieved from http://firstmonday.org/htbin/cgiwrap/bin/ojs/index.php/fm/article/view/608/529

Heidegger, M. (1968). Existence and being. Chicago, IL: Henry Regnery.

Hirst, M., \& Harrison, J. (2007). Communication and new media: From broadcast to narrowcast. South Melbourne: Oxford University Press. 
Hoffman, D., Novak, T., \& Schlosser, A. (2000). The evolution of the digital divide: How gaps in internet access may impact electronic commerce. Journal of Computer Mediated Communication, 5(3). Retrieved from http://onlinelibrary.wiley.com/doi/10.1111/j.1083-6101.2000.tb00341.x/full

It's the links, stupid. (2006, April 20). The Economist. Retrieved from http://www.economist.com/surveys/displaystory.cfm?story_id=6794172

Jenkins, H. (2006). Convergence culture: Where old and new media collide. New York: New York University Press.

Johannesen, R. (2001). Ethics in human communication ( $5^{\text {th }}$ ed.). Prospect Heights, IL: Waveland Press.

Johnson, S. (2001). Emergence: The connected lives of ants, brains, cities and software. New York: Scribner.

Jowett, G., \& O'Donnell, V. (2005). Propaganda and persuasion (4 ${ }^{\text {th }}$ ed.). Thousand Oaks, CA: Sage.

Keen, A. (2007). The cult of the amateur: How today's internet is killing our culture. New York: Doubleday.

Lash, S. (2002). Critique of information. London: Sage.

Leadbeater, C., \& Miller, P. (2004). The pro-am revolution: How enthusiasts are changing our economy and society. London: Demos.

Lévy, P. (1997). Collective intelligence: Mankind's emerging world of cyberspace. Cambridge, MA: Perseus Books.

Lewis, J. (2001). The end of cinema as we know it: American film in the nineties. New York: New York University Press.

Lievrouw, L., \& Livingstone, S. (Eds.). (2005). The handbook of new media ( $2^{\text {nd }}$ ed.). London: Sage.

Lister, M., Dovey, J., Giddings, S., Grant, I., \& Kelly, K. (2009). New media: A critical introduction $\left(2^{\text {nd }}\right.$ ed.). Abingdon, Oxfordshire, UK and New York: Routledge.

Lovink, G. (2007, February 1). Blogging, the nihilist impulse. Eurozine, Lettre internationale, 73. Retrieved from http://www.eurozine.com/articles/2007-01-02-lovink-en.html

MacManus, R. (2005, September 7). What is Web 2.0? Retrieved from http://blogs.zdnet.com/web2explorer/?p=5

Macnamara, J. (2008). Internet media and the public sphere: The 2007 Australian e-electioneering experience. Media International Australia, 129, 7-19.

Macnamara, J. (2009). Australian federal government online public consultation trials: Local learnings in e-democracy. In T. Flew (Ed.), Communication, creativity and global citizenship: Refereed proceedings of the Australian and New Zealand Communication Association Annual Conference, Queensland University of Technology, Brisbane, 8-10 July. Retrieved from http://www.proceedings.anzca09.org/

Macnamara, J. (2010). The $21^{\text {st }}$ century media (r)evolution: Emergent communication practices. New York: Peter Lang.

Macquarie Dictionary. (2008). WordGenius PC edition.

Man, J. (2000). Alpha beta: How our alphabet shaped the western world. London: Hodder Headline.

Manovich, L. (2002). The language of new media. Cambridge, MA: MIT Press.

McChesney, R. (2000). So much for the magic of technology and the free markets: The world wide web and the corporate media system. In A. Herman \& T. Swiss (Eds.), The world wide web and contemporary cultural theory (pp. 5-35). New York: Routledge.

McChesney, R. (2008). The political economy of media: Enduring issues, emerging dilemmas. New York: Monthly Review Press.

McLuhan, M. (1964). Understanding media: The extensions of man. New York: McGraw-Hill.

McMillan, S. (2002). Exploring models of interactivity from multiple research traditions: Users, documents and systems. In L. Lievrouw \& S. Livingstone (Eds.), Handbook of new media (pp. 163-182). London: Sage.

McNair, B. (2006). Cultural chaos: Journalism, news and power in a globalized world. New York: Routledge.

Merholz, P. (2005). It's not about the technology. Retrieved from http://www.peterme.com/archives/000560.html

Meyer, P. (2004). The vanishing newspaper: Saving journalism in the information age. Columbia, $\mathrm{OH}$ : University of Missouri Press. 
Meyer, P. (2008). The elite newspaper of the future. American Journalism Review, OctoberNovember. Retrieved from http://www.ajr.org/Article.asp?id=4605

Miller, D., \& Slater, D. (2000). The internet: An ethnographic approach. London: Berg.

Mosco, V. (1996). The political economy of communication. Thousand Oaks, CA: Sage.

Mosco, V. (2004). The digital sublime: Myth, power and cyberspace. Cambridge, MA: MIT Press.

Mosco, V. (2009). The political economy of communication ( $2^{\text {nd }}$ ed.). London: Sage.

Murdoch, R. (2005, April 13). Speech to the American Society of Newspaper Editors, New York. Retrieved from http://www.newscorp.com/news/news_247.html

National Telecommunications and Information Administration. (2000, October). Falling through the net: Toward digital inclusion. Report on Americans' access to technology. Washington, DC: US Department of Commerce.

Needham, J. (1986). Paper and Printing, Part 1. In Science and civilisation in China, Volume 5: Chemistry and chemical technology. Taipei: Caves Books.

Negroponte, N. (1995). Being digital. New York: Knopf.

Newbold, C., Boyd-Barret, O., \& Van Den Bulck, H. (2002). The media book. London: Arnold.

Nightingale, V. (2007). Emergence, search and social networking. In V. Nightingale \& T. Dwyer (Eds.), New media worlds: Challenges for convergence (pp. 291-307). South Melbourne: Oxford University Press.

Nightingale, V., \& Dwyer, T. (Eds.). (2007). New media worlds: Challenges for convergence. South Melbourne: Oxford University Press.

Norris, P. (2001). Digital divide: Civic engagement, information poverty, and the internet worldwide. Cambridge, UK: Cambridge University Press.

Novak, T., \& Hoffman, D. (1998). Bridging the digital divide: The impact of race on computer access and internet use. Project 2000, Vanderbilt University. Retrieved from http://www.vanderbilt.edu/News/register/April20_98/vr13.html

O'Reilly, T. (2005, September 30). What is web 2.0: Design patterns and business models for the next generation of software. O'Reilly blog. Retrieved from http://www.oreillynet.com/pub/a/oreilly/tim/news/2005/09/30/what-is-web-20.html

Pavlik, J. (2008). Media in the digital age. New York: Columbia University Press.

Poster, M. (1995). The second media age. Cambridge, UK: Polity.

Printing. (2009). Encyclopaedia Britannica Online. Retrieved from http://www.britannica.com/EBchecked/topic/477017/printing/36833/The-invention-of-printing

Quinn, S. (2008, July 24). Why the media is on the move. The Age, p. 23.

Reckwitz, A. (2002). Toward a theory of social practices. European Journal of Social Theory, 5(2), 243-264.

Rheingold, H. (1993). The virtual community: Homesteading on the electronic frontier. Reading, MA: Addison-Wesley.

Rheingold, H. (2002). Smart mobs: The next social revolution. Cambridge, MA: Perseus Publishing.

Rosen, J. (2006, June 27). The people formerly known as the audience. PressThink blog. Retrieved from http://journalism.nyu.edu/pubzone/weblogs/pressthink/2006/06/27/ppl_frmr.html

Rushkoff, D. (2003). Open source democracy: How online communication is changing offline politics. London: Demos.

Rust, R., \& Oliver, R. (1994). The death of advertising. Journal of Advertising, 23(4), December, $71-$ 77. Retrieved from http://www.richardwoliver.com/PDFs/JournalOfAdvertising.pdf

Schatzki, T. (1999). Social practices: A Wittgenstinian approach to human activity and the social. Cambridge, UK: Cambridge University Press.

Schiller, D. (2000). Digital capitalism: A status report on the corporate commonwealth of information. In A. Valdivia (Ed.), A companion to media studies (pp. 137-156). Malden, MA: Blackwell.

Severin, W., \& Tankard, J. (2001). Communication theories: Origins, methods, and uses in the mass media. New York: Addison Wesley Longman.

Smith A. (1980). Goodbye Gutenberg: The newspaper revolution of the 1980s. New York: Oxford University Press.

Smith, A., \& Rainie, L. (2008). The internet and the 2008 election. Pew Internet \& American Life Project report, 15 June, Pew Research Center, Washington DC. Retrieved from http://www.pewinternet.org/PPF/r/252/report_display.asp 
Stone, M. (2002). The backpack journalist is a mush of mediocrity. Online Journalism Review, 2, April. Retrieved from http://www.ojr.org/ojr/workplace/1017771634.php

Szuprowicz, B. (1995). Multimedia networking. New York: McGraw-Hill.

Technorati. (2009). State of the Blogosphere 2008. Author. Retrieved from http://technorati.com/blogging/state-of-the-blogosphere/

Toffler, A. (1970). Future shock. New York: Random House.

Toffler, A. (1980). The third wave. New York: William Morrow.

Wells, W., Spence-Stone, R., Moriarty, S., \& Burnett, J. (2008). Advertising principles and practice (Australian ed.). Frenchs Forest, Sydney: Pearson Australia.

Woolgar, S. (2002). Five rules of virtuality. In Virtual society? Technology, cyberbole, reality (pp. 122). Oxford, UK: Oxford University Press.

Wortham, J. (2007, December 17). After 10 years of blogs: The future's brighter than ever. Wired. Retrieved from http://www.wired.com/entertainment/theweb/news/2007/12/blog_anniversary

Wrench, J., McCroskey, J., \& Richmond, V. (2008). Human communication in everyday life: Explanations and applications. Boston, MA: Pearson Education.

YouTube. (2010). YouTube fact sheet. Retrieved from http://www.youtube.com/t/fact_sheet

1 Printing was first developed in China around the $8^{\text {th }}$ century according to several scholars and block printing, the forerunning to modern forms of printing was developed in China around 1040 according to Needham (1986, p. 201).

2 In Western societies, invention of the printing press is most widely attributed to Johannes Gensfleisch zur Laden, known as Johannes Gutenberg (c. 1398-1468), a goldsmith working in Mainz, Strasbourg circa 14361440, although others experimented with movable wooden character types in the 1430s (Deibert, 1997, p. 64). Dates of Gutenberg's invention vary from 1436 when he is believed to have developed a design (Wrench, McCroskey \& Richmond 2008, p. 306), 1440 when a working model was completed, to the early 1450s when the first printing was publicly distributed in Europe (e.g. the first printed Bibles in 1452-53). Printing in various forms was developed in China from around $200 \mathrm{AD}$ and existed in various parts of Asia including China, Korea and Japan by the end of the first millennium ("Printing", 2009 in Encyclopaedia Britannica). Block printing was first developed in China around 600 AD using wood blocks (Man, 2000), and moveable type printing was developed in China around 1040 (Needham, 1986, p. 201).

3 Ohmynews.com was established in South Korea in 2000 and has as its theme "every citizen is a reporter". Only around 20 per cent of the online 'newspaper' is produced by staff, with a claimed 50,000 citizen reporters providing content. An English version (Ohmynews International) has also been launched with 3,000 global citizen reporters (See http://www.ohmynewsinternational.com)

4 The term Weblog was coined in 1997 by John Barger (Wortham, 2007), before being shortened to 'blog' by Peter Merholz (2005).

5 SMS stands for Short Message Service, commonly understood as text messages transmitted via mobile telephony networks. MMS stands for Multimedia Message Service which can transmit photographic and/or video content. IM refers to Instant Messaging.

* Jim Macnamara PhD, MA, FPRIA, FAMI, CPM, FAMEC is Professor of Public Communication at the University of Technology Sydney and Director of the Australian Centre of Public Communication, positions he took up in 2007 after a 30-year professional career spanning journalism, public relations, advertising, and media research. He is the author of 12 books including 'The $21^{\text {st }}$ Century Media (R)evolution: Emergent Communication Practices' published by Peter Lang, New York in 2010. 